\title{
Microfluidic and Nanofluidic Resistive Pulse Sensing: A Review
}

\author{
Yongxin Song ${ }^{1}$, Junyan Zhang ${ }^{1}$ and Dongqing $\mathrm{Li}^{2, *}$ \\ 1 Department of Marine Engineering, Dalian Maritime University, Dalian 116026, China; \\ yongxin@dlmu.edu.cn (Y.S.); junyan@dlmu.edu.cn (J.Z.) \\ 2 Department of Mechanical and Mechatronics Engineering, University of Waterloo, \\ Waterloo, ON N2L 3G1, Canada \\ * Correspondence: dongqing.li@uwaterloo.ca or dongqing@mme.uwaterloo.ca; \\ Tel.: +1-519-888-4567 (ext. 38682)
}

Received: 17 April 2017; Accepted: 21 June 2017; Published: 25 June 2017

\begin{abstract}
The resistive pulse sensing (RPS) method based on the Coulter principle is a powerful method for particle counting and sizing in electrolyte solutions. With the advancement of micro- and nano-fabrication technologies, microfluidic and nanofluidic resistive pulse sensing technologies and devices have been developed. Due to the unique advantages of microfluidics and nanofluidics, RPS sensors are enabled with more functions with greatly improved sensitivity and throughput and thus have wide applications in fields of biomedical research, clinical diagnosis, and so on. Firstly, this paper reviews some basic theories of particle sizing and counting. Emphasis is then given to the latest development of microfuidic and nanofluidic RPS technologies within the last 6 years, ranging from some new phenomena, methods of improving the sensitivity and throughput, and their applications, to some popular nanopore or nanochannel fabrication techniques. The future research directions and challenges on microfluidic and nanofluidic RPS are also outlined.
\end{abstract}

Keywords: resistive pulse sensing; particle sizing and counting; microfluidics and nanofluidics; review

\section{Introduction}

Accurately determining the size and number of particles and cells in electrolyte solutions is an important task in many fields, such as biomedical research [1-6], clinical diagnosis [7-12], and environmental monitoring. Among the methods for particle counting and sizing [13], resistive pulse sensing (also called the Coulter principle) probably is the most popular method. This method was invented by Coulter [14], aiming to replace manual cell counting with an automatic device. In a Coulter counter, a small insulating orifice is immersed into an electrolyte solution with suspended particles. A direct current (DC) voltage is applied through two electrodes placed across the orifice and an electrical current is conducted by the electrolyte solution and the orifice creates a "sensing zone". When a particle passes through the orifice, due to the different resistivity of the particle and electrolyte solution, a temporary electrical resistance change across the orifice is generated. This change is measured in terms of a voltage or a current pulse, whose magnitude is proportional to the volume of the particle for a given orifice. With the invention of Coulter counter, flow cytometry, which is widely used for detecting, counting, sizing cells and particles with a throughput of thousands of cells per second [15-22], became available [23]. The traditional flow cytometer, however, is bulky in size due to bulky pumps, tubes, valves, and other auxiliary components. Furthermore, it is expensive and cannot handle small volumes of samples.

With the advancement of Lab-on-a-chip technologies [24-30], microfluidic and nanofluidic RPS sensors with high sensitivity and accuracy were developed. Besides the basic functions for particle sizing and counting, a nano-RPS sensor can also characterize nanoparticles, DNA, viruses, antigens 
and so on. Such advancements greatly enrich the powerful abilities of the RPS technology and make the development of a low cost and portable flow cytometer possible.

This paper aims to review the latest development of microfuidic and nanofluidic RPS technologies within the last 6 years, ranging from some new phenomena, nanochannel or nanopore fabrication technologies, methods of improving the sensitivity and throughput, as well as their applications. The paper begins by introducing some basic theories of particle sizing and counting of microfluidic RPS sensors. Then, some interesting phenomena and applications of microfluidic and nanofluidic RPS are reviewed. At the end, the future research directions and challenges on microfluidic and nanofluidic RPS are discussed.

\section{Working Principle and New Sensing Phenomena}

Microfluidic and nanofluidic RPS employ the principle of the Coulter counter in microfluidic or nanofluidic channels for particle counting and sizing. The working principle and typical system setup is shown in Figure 1. For the system shown in Figure 1, an electrical field is applied across a sensing orifice whose size is much smaller than the main channel which is filled with an electrolyte solution. Each particle passing the sensing orifice will generate a resistive pulse which is processed by the amplification circuit, the data acquisition device, and the computer. Each particle will generate one signal pulse and the magnitude of the signal represents the volume ratio of the particle and the sensing gate. In this way, particle sizing and counting are achieved.

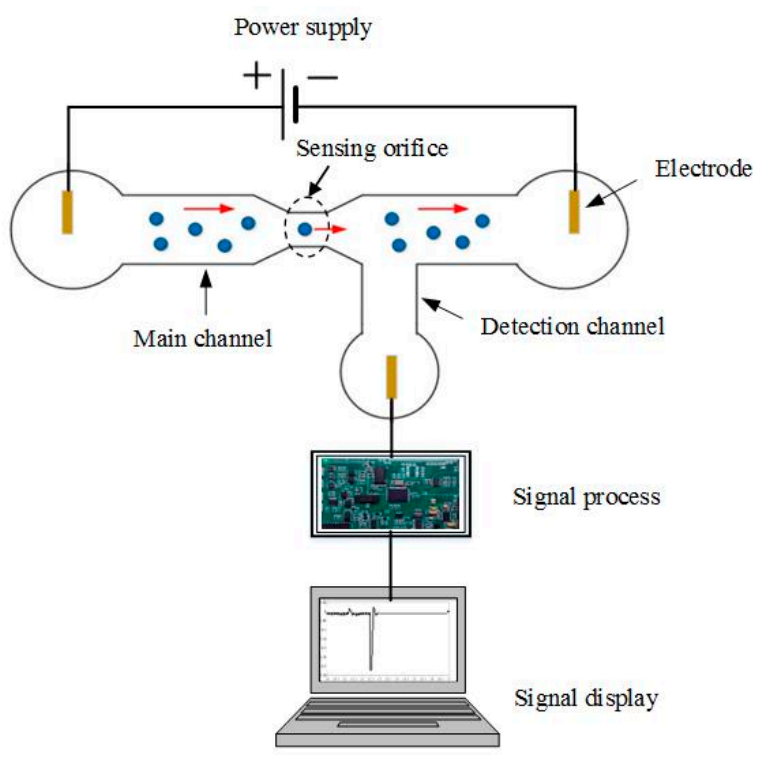

Figure 1. Working principle of a microfluidic resistive pulse sensing (RPS) system.

It should be noted that both DC and alternative current (AC) fields can be applied (named as DC RPS and AC RPS, respectively). For the DC RPS, the system is very simple without using the bulky AC power source and the complicated signal processing circuit. However, the polarization of the electrode in electrolyte solution will increase the electric resistance of the main channel and thus is adverse to the sensitivity of the system. [31-33]. Such polarization effects can be avoided by using an AC electric field which can decrease the polarization resistance by increasing the excitation frequency [33]. In order to minimize the stray capacitance effects [34], however, appropriate frequency must be carefully determined depending on the specific chip design [31,32,35-37].

For particle sizing with the RPS method, the most important question is how to evaluate particle's size based on the detected signal. That is, the relationship between the measured magnitudes of signals and the sizes of the sensing orifice (or sensing channel) and particles must be determined. Such a relationship can be determined by calculating the resistance change caused by a particle 
entering the sensing channel $(\Delta R)$. Table 1 summarizes the relative electrical resistance change caused by spherical particles with different diameters.

Table 1. Relative resistance changes caused by particles passing a sensing orifice. $D$ and $L$ are the diameter and length of the sensing orifice, $d$ is the diameter of the particle.

\begin{tabular}{cc}
\hline Relative Particle Diameter $(d / D)$ & Relative Resistance Change $(\boldsymbol{\Delta R} / \mathbf{R})$ \\
\hline Infinite smaller diameter [38] & $\frac{d^{3}}{D^{2} L}\left[\frac{D^{2}}{2 L^{2}}+\frac{d^{3}}{\sqrt{1+(D / L)^{2}}}\right] F\left(\frac{d^{3}}{D^{3}}\right)$ \\
Smaller diameter [39] & $\frac{d^{3}}{D^{2} L} \cdot \frac{1}{1-0.8(d / D)^{3}}$ \\
Medium diameter [40,41] & $\frac{D}{L}\left[\frac{\arcsin (d / D)}{\sqrt{1-(d / D)^{2}}}-\frac{d}{D}\right]$ \\
Larger diameter [42] &
\end{tabular}

It should be noted that the equations shown in Table 1 were derived based on the assumption that a spherical particle moves along the centerline of a cylindrical microchannel. With the advancement of micro and nanofabrication technology, different types of micro and nanochannels were available and new RPS phenomena in sub-microscale and nanoscale have been demonstrated recently. One interesting phenomenon recently discovered is the generation of a double-peak (resistive-and-conductive peak) when a particle passes through the sensing pore $[44,45]$. Such a phenomenon is totally different from the classical Coulter theory. Menestrina et al. [45] used a polyethylene terephthalate (PET) pore (12 $\mu \mathrm{m}$ long and $500 \mathrm{~nm}-1.5 \mu \mathrm{m}$ in diameter) for RPS detection of particles of several hundred nanometers in $\mathrm{KCl}$ solution with different concentrations. They found that double peaks, first a downward resistive peak and then an upward conductive peak, will be generated when the concentration of the $\mathrm{KCl}$ solution was below $300 \mathrm{mM}$. Through numerical simulations and experimental verifications, the authors concluded that the positive peak (conductive) is caused by the modulated ionic concentrations induced by the charged particles entering into the sensing pore.

Weatherall et al. [44] also experimentally investigated the double-peak phenomenon when measuring $200 \mathrm{~nm}$ carboxylate polystyrene spherical particles with a tunable RPS method. They found that the onset electrolyte concentration for double-peak formation is about $50 \mathrm{mM}$. More importantly, the formation of a double-peak is due to the ionic concentration polarization. They also found that the shape of the double-peak depends both on the moving directions of the particle and the applied voltages. For example, a positive voltage bias and a positive hydraulic pressure will only generate a resistive pulse. With a negative voltage bias and a positive pressure, however, a conductive and resistive pulse will be generated.

Considering the 'end effects' of the sensing pore, Willmott et al. [46,47] built up a semi-analytic model to simulate the shapes of the pulses. They found that end effects are prominent when the center of the particle is less than one radius inside the pore entrance. They also found that asymmetry is more obvious for larger and slower moving particles. Such results are valuable for evaluating a particle's size based on the measured pulse because most of the sensing pores are not of the ideal shape with a constant cross-section in practice.

The geometry effects of a nanopore on RPS nanoparticle sensing were also investigated. It was found that the length [48], thickness [49], tip diameter [50], and base ratio [51] of the silicon nitride membrane nanopores can greatly influence the electric field around the ends of the nanopores. More recently, Kaya et al. studied the influence of the cone angle of a conically shaped poly(ethylene terephthalate) (PET) membrane nanopore on DNA sensing. They found that the electric field at the tip of the nanopore increases with the increase in the cone angel. As a result, the magnitude of the pulse will also be increased with the increased cone angel [52]. 
Beside the geometry of the nanopores, the surface charges at the interface of nanopore-electrolyte solution can also influence the magnitude and duration of a RPS signal pulse. Liu et al. [53] showed that the surface charges can either increase or decrease the magnitude of the signal pulse depending on the positive or negative potential bias applied across the sensing channel. Recently, Weatherall et al. [54] found that particles near the edge of a tunable nanopore entrance generate larger RPS signals. The smallest RPS signal is generated by a particle moving along the center line of the nanopore.

Recent studies also showed that both the shape and material of a particle can influence the detected RPS signals. For example, using a rod-like Au particle (several micrometers in length and several hundred nanometers in diameter) and a tunable elastomeric membrane pore, Platt et al. [55] studied the effects of shape of the particle on RPS signals. They found that the full width at half maximum of the RPS signal can be used to characterize the rod length. More importantly, they showed that for the rod-like particles, the measured current change remains unchanged or slightly increased with the increase in the pore size. However, the current change caused by a spherical particle is decreased.

Lee's study showed that the magnitude of a RPS signal generated by an elongated nanoparticle is larger than that by a spherical nanoparticle of the same volume [56]. Song et al. [57] studied the effect of induced surface charge of metal particles on RPS particle sizing. The experimental results showed that the magnitude of the RPS signals generated by $5 \mu \mathrm{m}$ magnetic particles is larger than that of a $5 \mu \mathrm{m}$ polystyrene particle under the same condition, as is shown in Figure 2. Such results are due to the thicker electrical double layer (EDL) formed by the induced charges around the magnetic particles.

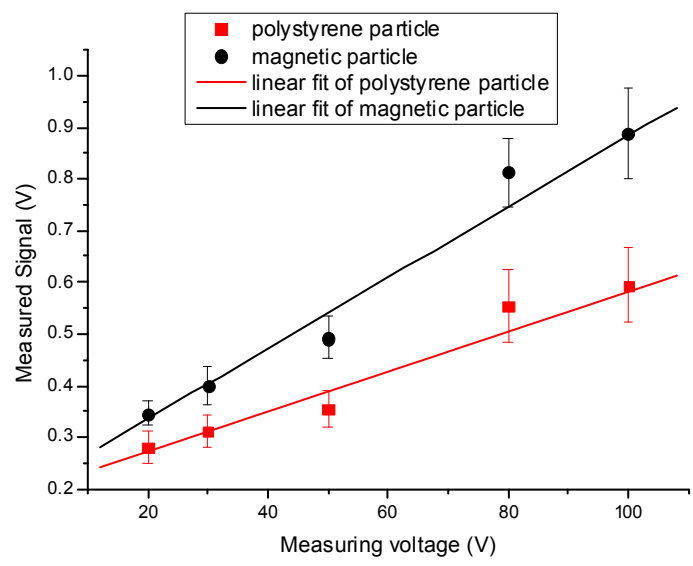

(a)

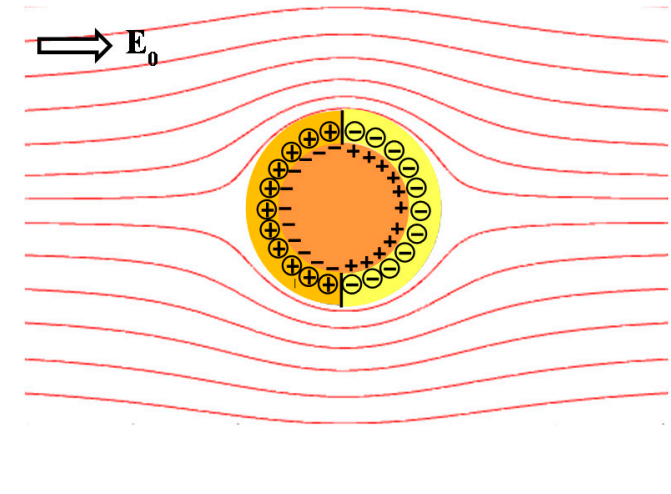

(b)

Figure 2. (a) Dependence of the magnitudes of measured RPS signals on the applied voltages and (b) the induced electrical double layer.

These new phenomena mentioned above are important and not covered in the traditional RPS theory. Such phenomena should be well considered for particle size evaluation with the RPS method.

\section{Methods for Throughput and Sensitivity Improvement}

\subsection{Throughput}

One key advantage of microfluidic RPS is its simplicity, because the bulky pumps and valves are no longer needed due to the using of a micro- or nanoscale-sized channel or sensing pore and thus a greatly decreased sample volume. Therefore, microfluidic and nanofluidic RPS is very promising to be developed into portable lab-on-a-chip (LOC) devices. However, the throughput of a portable device is relative low due to the slow sample transportation velocity in a microfluidic channel. The sensitivity is also limited by the limited ability of fabricating a small sensing channel or pore and the simple data processing circuit. For microfluidic and nanofluidic RPS, the throughput and sensitivity are generally coupled with each other. A smaller sensing channel or sensing pore is needed in order to have a higher 
sensitivity. Achieving this, however, will lower the throughput due to the constraint of using the smaller sensing channel.

To improve the counting throughput, Jagtiani et al. [32] developed a frequency division multiplexing method which can encodes each channel with a specific frequency with a single pair of electrodes and process the signals with a single electronic system. Such a method enables monitoring multi-channels individually and obtaining an 300\% improvement of throughput over a single-channel device. For this design, however, each channel needs one specific signal process channel to decode the signals.

Following a similar idea, Liu et al. [58] designed novel coplanar electrodes that can generate orthogonal digital codes when particles pass over the electrodes. The orthogonal digital codes were then decoded by the Code Division Multiple Access (CDMA) principle. Such a design, which can even differentiate the overlapped signals with $>90 \%$ accuracy, can be easily extended to orthogonally counting particles in an arbitrary number of microfluidic channels and thus provides a very promising approach for solving the throughput problem of a microfluidic flow cytometer.

Song et al. [59] also put forward a novel method to improve the throughput of a DC RPS device. They designed a sensitive differential microfluidic sensor with multiple detecting channels and one common reference channel (Figure 3). With seven detecting channels, an average throughput of 7140 cells $/ \mathrm{min}$ under a flow rate of $10 \mu \mathrm{L} / \mathrm{min}$ was achieved. Counting throughput can be further increased by increasing the number of the detecting channels. It should be noted that a reference channel makes a good balance between the sensitivity and the throughput.
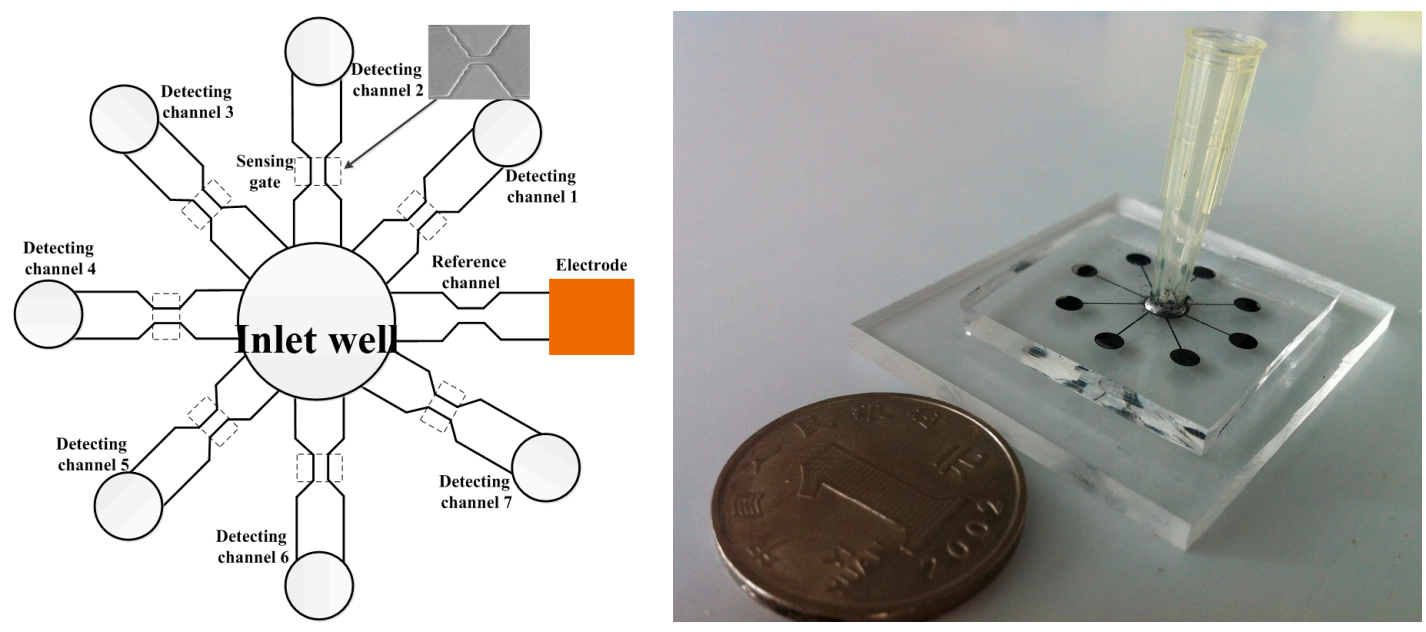

Figure 3. The structure of the high throughput microfluidic chip.

Rather than putting efforts on chip design innovation, Castillo-Fernandez et al. [60] adopted a signal post-treating approach to improve the throughput. They designed an electronic system that allowed a counting throughput of about of 500 counts/s.

\subsection{Sensitivity}

Theoretically, the sensitivity of the RPS sensor is mainly determined by the volume ratio of the particle and the sensing channel as well as the noise level of the electronic system. Therefore, sensitivity can be improved either by increasing the volume ratio or by using advanced signal processing instruments to cancel the noise.

One way to increase the volume ratio is to decrease the volume of the sensing channel. For smaller particle detection, such as DNA, proteins, and viruses, a nano-sized sensing channel or pore is needed. The details about the methods of fabricating such channels or pores will be reviewed and discussed 
in Section 5. Here, several other novel methods on decreasing the volume of the sensing channel are reviewed first.

One novel and simple way is to use less conductive focusing solutions to decrease the volume of the sensing channel. Choi et al. [61] used hexadecane as the focusing solution to hydraulically control the width of the passage for the sample solution. The sample solution is focused by the focusing solution (hexadecane) to pass the sensing region. Due to the very low conductivity of hexadecane, the electric field only exists in the sample solution and becomes concentrated in the focused region. In this way, the volume in the sensing region is narrowed and can be flexibly controlled by the flow rate of the focusing solution. Such a RPS sensor has a controllable range of sensitivity and was successfully applied for submicron-sized bacterial detection with a $30 \mu \mathrm{m}$ wide detection channel.

One problem associated with using oil as the focusing solution is that the large surface tension at the oil-water interface can make the flow unstable. As a result, the sensing volume will also be changing and thus noise level is increased too [62]. To solve this problem, Bernabini et al. added some surfactants into the oil (focusing solution) to stabilize the oil-sample solution interface. Due to the increased stability of the sensing volume by using an oil/surfactant mixture, detection of $1 \mu \mathrm{m}$ polystyrene particles and discrimination of bacteria and polystyrene particles of similar size with a $200 \mu \mathrm{m}$ wide sensing channel were achieved [62].

For the above two studies, it should be noted that they used two or four electrodes to apply an AC electric field and the sample solutions were transported by pressure-driven flow. For these designs, the distance between the electrodes defines the length of the sensing region. The focusing solution was only used to decrease the width of the sensing region. More recently, Liu et al. [63] reported a novel electrokinetic-flow-focusing method to narrow the size of the sensing channel and thus improve the sensitivity. This method is particularly useful for a DC RPS system with an elelctrokinetically-driven flow. Figure 4 shows the structure of this novel microfluidic RPS sensor and its working principle. The microfluidic chip has inlet and outlet wells, one main channel, two detecting channels, two focusing channels, and the corresponding wells. The key feature of this sensor is that the focusing solution can flow only from the upstream focusing channel to the downstream focusing channel. In this way, the sensitivity is greatly improved. As a result, detection of $1 \mu \mathrm{m}$ with a physical sensing gate of $30 \mu \mathrm{m} \times 40 \mu \mathrm{m} \times 10 \mu \mathrm{m}$ (width $\times$ length $\times$ height) was successfully achieved (Figure 5).

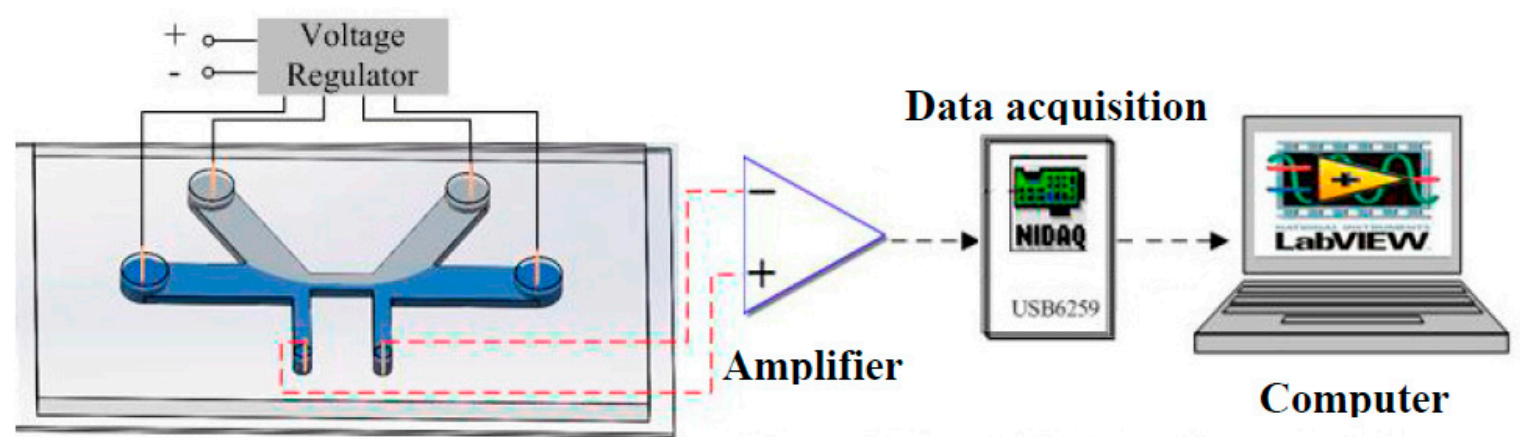

Microfluidic chip

(a)

Figure 4. Cont. 


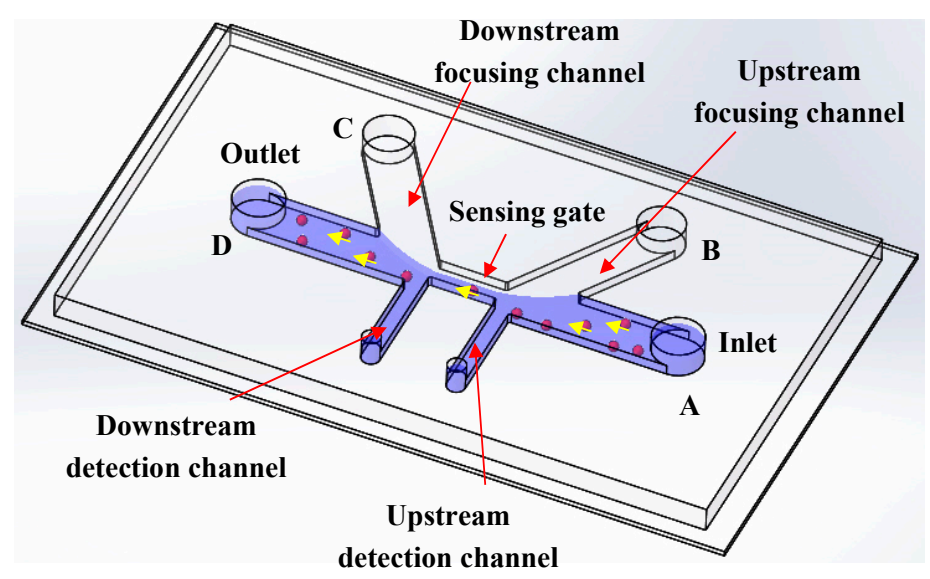

(b)

Figure 4. (a) A schematic diagram of the system setup, and (b) the structure of the microfluidic chip.

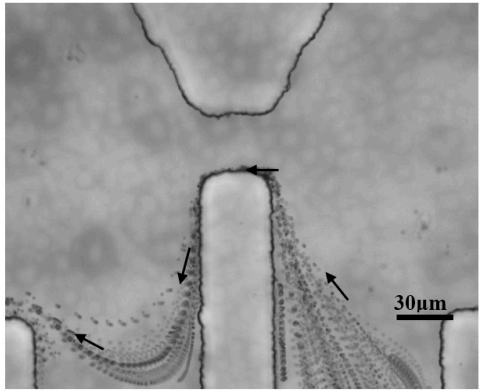

(a)

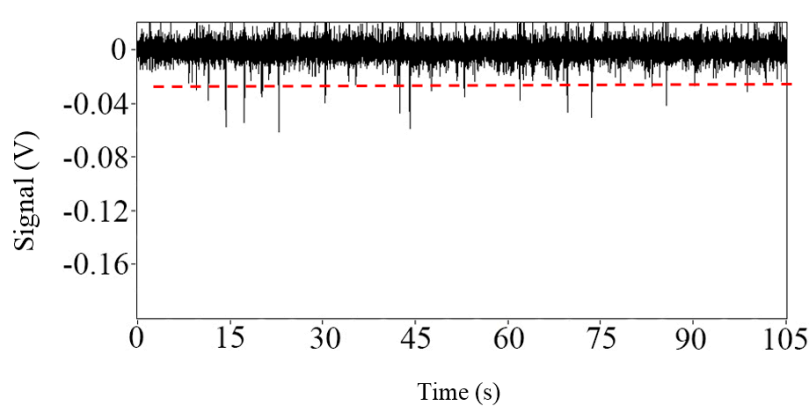

(b)

Figure 5. (a) Typical flow trajectory, and (b) detected RPS signals of $1 \mu \mathrm{m}$ particles $\left(V_{A}=27 \mathrm{~V}, V_{B}=52 \mathrm{~V}\right.$, $\mathrm{V}_{\mathrm{C}}=0 \mathrm{~V}$ and $\left.\mathrm{V}_{\mathrm{D}}=24 \mathrm{~V}\right)$.

\section{Applications}

With the improved RPS sensitivity, especially the ability of fabricating a nano-RPS sensor, label-free particle detection in nanoscale, such as detection of DNA, proteins, viruses, and so on, were possible. With the measured RPS signals, nanoparticle characterization was also reported. In this section, we will review the recent developments on the typical applications of RPS technology in submicroand nanoscale.

\subsection{DNA Detection and Analysis}

With the first demonstration of RPS detection of single stranded DNA detection by a biological $\alpha$-hemolysin pore [64], nano-RPS now is an attractive tool for label-free DNA detection with the distinctive advantages of its simplicity and high sensitivity [65-71]. The commercially available qNano device exemplifies the strength of this technology.

Among the recent investigations, the mostly common used approach of DNA detection with RPS is to detect the change caused by the binding of DNA to a particle. For example, the change of the width and frequency of the RPS signals caused by the binding of thrombin to DNA-coated magnetic beads [67], the change in the full-width half maximum (FWHM) caused by DNA strands hybridized with the probe-grafted magnetic particles [72], have been used for DNA identification.

To increase the small size difference by the adsorption of DNA, an approach of amplification was adopted by Kühnemund [73] and Yang [70]. The key idea is to increase the amount of DNA and thus increase the signal difference and detection sensitivity. Firstly, target DNA, together with padlock probes and capture oligo, is captured by the magnetic particle. After amplification, the magnetic 
particles are measured with the RPS system. For the particles with target DNA, it will generate signals with larger magnitude and wider FWHM.

In 2013, Traversi et al. [74] fabricated graphene and SiNx nanopores with which the electrokinetic translocation behavior of pNEB DNA and $\lambda$-DNA was measured. Since the graphene membrane can be as thin as $0.0335 \mathrm{~nm}$, comparative to the distance between two bases in a DNA chain, it is promising for fabricating a DNA sequencing device. Hernándezainsa et al. [75] fabricated a glass nanocapillary (with a central needle hole) and studied the structures of DNA origami using both visual observation and RPS detection. This demonstrates the possibility of selective detection of double-strand DNA and thus the great potential for DNA sequencing with the RPS method. More recently, Sischka et al. [76] studied the translocation force on DNA molecules in nanopores. It was found that the membrane thickness had a great influence on the translocation of DNA molecules.

\subsection{Label-Free Protein Detection}

With the improved sensitivity for particle sizing, especially the ability to fabricate a nano-RPS sensor, label-free detection of a specific kind of nanoparticles, such as proteins and DNA, from a mixture solution becomes possible. Rodriguez-Trujilloa et al. [77] measured the specific protein concentrations in a suspension with a microfluidic RPS system. Briefly, bead oligomers were formed when the two functionalized polystyrene beads and the rat IgG serum were mixed together. Such oligomers are larger in size and will generate RPS signals with larger magnitude. By comparing the magnitudes of the detected signals, the presence of the target protein can be easily determined. However, more single bead will be available with the increased protein concentration. The authors attributed such results to the binding and blocking of more sites on the surface of the two beads under high protein concentration.

Following a similar idea, RPS detection of a cancer biomarker [78], human ferritin [79], and even single-molecule proteins [80] were also demonstrated. It should be emphasized that for RPS detection, any specific binding will be reflected by the detected electric signals. Thus, fluorescent labeling is no longer needed. This is much more advantageous and attractive in saving time and simplifying detection.

\subsection{Nanoparticle Characterization}

The nano-RPS device is a new, yet powerful tool for nanoparticle analysis. Based on a single-particle measurement, much useful information, such as size and concentration distribution, surface charges, and even translocation behavior can be reliably obtained [56,81-86].

Vogel et al. [81] demonstrated the accuracy and reliability of sizing nano-sized particles with a tunable RPS sensor made of polyurethane. The nano-RPS system was fabricated by mounting a resizable elastomeric thermoplastic polyurethane (TPU) membrane on the q-Nano device. The membrane was stretched open to different pore sizes. The experimental results showed that the sizes of different particles, for example polymethyl methacrylate (PMMA) and nonfunctionalized polystyrene particles, adenovirus, and so on, can be accurately evaluated based on the pre-obtained calibration curve. Following a similar calibration methodology, Roberts et al. [82] measured the concentrations of the marine photosynthetic cyanobacterium Prochlorococcus (with a diameter of $600 \mathrm{~nm}$ ) by using a tunable polyurethane nanopore. A good agreement with the results from microscopy counting was found. Pal et al. [85] measured the size distribution and concentration of engineered nanomaterials in cell culture media with a tunable nanopore RPS method. They found that TRPS technology offers higher resolution and sensitivity compared to the dynamic light scattering (DLS) method. Due to the high accuracy and resolution in sizing nanoparticle, the nanopore RPS sensing technique was applied to characterize the swelling of pH-responsive, polymeric expansile nanoparticles by Colby et al. [83], and to measure the size and the surface charge of silica nanoparticles in serum by Sikora et al. [87]. Compared with the results from other methods, such as transmission electron microscopy, differential centrifugal sedimentation (DCS), and dynamic light scattering (DLS), the tunable RPS sensor showed excellent performance in sensitivity and resolution. 
Fraikin et al. [84] developed a polydimethylsiloxane (PDMS) high-throughput nanoparticle RPS sensor that can size and determine the concentration of a nanoparticle suspension and unlabeled bacteriophage T7 in both salt solution and mouse blood plasma with a throughput of about 500,000 particles per second. With this sensor, the authors also firstly discovered some naturally occurring nanoparticles in the native blood plasma. Through both finite-element simulations and experimental verification, Lee investigated the geometry of the pore and the particle on the magnitudes of the detected RPS signals. The results showed that a conical pore can generate larger signals in magnitudes than a cylindrical pore. More importantly, both the size and shape of the nanoparticle can be simultaneously determined based on the magnitude and the $y$-position of $10 \%$ resistive pulse (y $10 \%)$ [56].

Besides sizing the bare nanoparticle, estimation of the thickness of the protein layer absorbed onto the nanoparticles in serum was also achieved, using a tunable RPS method by Sikora et al. [87]. Recently, Luo et al. reviewed the advances in the transport motion of a single nanoparticle by the RPS method, with an emphasis on the forces governing the translocation of low-aspect-ratio, non-deformable particles [86].

Determining the zeta potential, an important electrokinetic parameter, of carboxylated polystyrene nanoparticles can also be reliably achieved with the RPS method [88-92]. Eldridge et al. [89] measured the zeta potential of carboxylated polystyrene nanoparticles. The idea is to find the critical pressure at which the drag forces of the pressure-driven flow and electroosmotic flow and the electrophoretic force exerted on the nanoparticle become balanced. Once balanced, the frequency of the signal pulse becomes minimum which can be used to calculate the electrophoretic mobility of the particle (also the zeta potential). By using the same system and the same measuring principle, Somerville et al. [90] measured the zeta potential of a water-in-oil emulsion, demonstrating the ability of measuring zeta potential of a single soft particle. To further evaluate the accuracy of this technique, Eldridge et al. [89] conducted experiments to measure particles with different diameters and surface charges and concluded that the full width half maximum (FWHM) duration of a signal pulse is more reliable in determining zeta potential. More recently, determining the zeta potential of DNA modified particles, discrimination of ssDNA, dsDNA, and small changes in base length for nucleotides were reported by Blundell et al. [69]. All of the above investigations demonstrate the power of the RPS technology to characterize bio-nanoparticles with high sensitivity and resolution.

\section{Fabrication of the Nano-Sensing Gate}

As reviewed above, there is an increasing interest in nano-RPS technology nowadays, propelled both from the interests in scientific understanding and promising applications in nanoscale. For a nano-RPS device, the most important component is the sensing orifice, which is normally in form of a nanopore or a nanochannel. Therefore, advancement in nanofabrication is vital for the development of a nano-RPS device. In addition to the several well-known review papers [86,93-95], we will review the latest development of fabricating two typical nanosensing orifices: nanopores and PDMS nanochannels.

\subsection{Nanopores}

The nanopore is one of the most widely used sensing orifices. Several review papers have already summarized the advances in the fabrication of solid-state nanopores and their applications on single-molecule sensing, DNA sequencing, genetics, medical diagnostics, and so on [93-95]. Generally speaking, a nanopore is typically of cylindrical [55,96-98] or conical [99-102] shape for use in RPS. In practice, most of the nanopore is of conical shape due to fabrication limitations. The conical nanopore is much more advantageous in sensitivity and accuracy due to the concentrated electric field at the entrance of a conical nanopore [99]. According to the material of a nanopore, it can be generally divided into two categories: biological nanopores and solid-state nanopores. 


\subsubsection{Biological Nanopores}

$\alpha$-Hemolysin ( $\alpha$-HL) is one typical biological nanopore used for RPS [103]. The hydrophilic $\alpha$-HL nanopore can self-assemble into a planar lipid membrane [104]. In 2012, Gopfrich et al. [105] fabricated an $\alpha$-HL nanopore which is embedded in lipid bilayers. The fabrication procedures can be found elsewhere [106]. Firstly, nanocapillaries of $200 \mathrm{~nm}$ diameter were fabricated by using a laser pipet puller. Then, this nanocapillary was put on the baseplate and a charge of Giant Unilamellar Vesicles (GUVs) was introduced. A few seconds later, a vesicle cracked on the nanotip area to create a nanobilayer. The formation of the nanobilayer was detected by measuring the current drop. This was a novel technique for nanobilayer manufacturing. Compared with other conventional bilayer methods, it provided a fast and stable way to make a bilayer.

However, the diameter of $\alpha$-HL nanopores is only $1.4 \mathrm{~nm}$, which is not suitable for the detection of some large molecules. To deal with this problem, some other biological membrane, such gareolysin [107], FhuA [108-110], and ClyA [111,112] hetero-oligomeric channels formed by NfpA and NfpB [113], were used. For biological nanopores, these are preferable for DNA sensing and sequencing. Although these nanopores achieved some success in a variety of applications, they had several weaknesses that hindered the advance of biological sensing in nanopores, for example, the low mechanical rigidity of the lipid membrane and shorter lifetime, etc. [114].

\subsubsection{Solid-State Nanopores}

Compared with the biological nanopores, a solid-state nanopore is durable and can be easily fabricated into the desired geometries. Such merits are advantageous for commercial application [115].

(1) Glass

Nanopores made of glass have a high mechanical rigidity and chemical resistance and have been widely used for RPS [114-120]. The most widely used method for glass nanopore fabrication is by the pulling-and-etching method, which is simple and readily available with a relatively high resolution $[117,120]$. Surface modification techniques can also be applied to the nanopore to achieve some specific purposes. Such a surface charge-modulated RPS sensor was proven to be highly sensitive and selective for target particle detection [118].

He et al. [119] reported a novel surface modification method that can be reliably applied for selectively detecting uric acid (UA). To modify the nanopore, firstly the inner surface of the capillary tip was coated with a poly (L-histidine) (PLH) monolayer, which worked as the substrate for Au assembly. This was followed by in situ chemical reduction of $\mathrm{AuCl}_{4}{ }^{-}$. An Au nanofilm and 2-thiouracil (2-TU) were generated and coated on the inner surface of the glass nanopore. The binding of the target molecules with the functioned 2-TU will change the ionic current of the RPS system which can be used for quantitative detection of UA.

\section{(2) Polymer Membranes}

Polymer membranes were a good material for fabricating the nano-orifice due to their excellent optical properties [121,122]. The track-etched method was a popular method for fabricating a nano-orifice in polymer membranes [52,123] because it is cost-saving, reproducible, and provides easy precision controlling [123]. For example, the authors [52] developed a novel method to accurately control the geometry of the poly(ethylene terephthalate) (PET) nanopore by controlling the proportion of methanol in the etching solution. Their results showed that the pore diameters can be accurately controlled by applying different amount of methanol in the alkali solution. The base diameters of the PET membrane were $512 \pm 30 \mathrm{~nm}$ and $928 \pm 33 \mathrm{~nm}$, with volume proportions of methanol of $0 \%$ and $10 \%$, respectively. The maximum deviation of the base diameters was only $5.8 \%$. 


\section{(3) Silicon Dioxide and Silicon Nitride}

The silicon-based nanopore is another popular nanopore which can be fabricated by using the electron beam writing method [124-126]. The diameter of such a nanopore can be smaller than $10 \mathrm{~nm}$ [125]. A chemically etched $\mathrm{SiN}_{x}$ nanopore was recently reported by Kwok $[127,128]$. The $\mathrm{SiN}_{x}$ membrane was immersed in $3.6 \mathrm{M} \mathrm{LiCl}$ buffer solution at $\mathrm{pH}=10$, where the dielectric breakdown was controlled. The nanopores manufactured by this method showed a very high resolution $(2.0 \pm 0.5 \mathrm{~nm}$ in diameter) and over $95 \%$ reproducibility.

Yanagi et al. [129] fabricated a silicon nitride nanopore with a diameter of 1-2 nm, using the technique of multilevel pulse-voltage injection (MPVI). There is a trans chamber and a cis chamber across the $10 \mathrm{~nm}$-thick $\mathrm{Si}_{3} \mathrm{~N}_{4}$ membrane. Two $\mathrm{Ag} / \mathrm{AgCl}$ electrodes were inserted into the two chambers and connected to an $\mathrm{AC}$ power source and an ammeter. The voltages were used to drill a nanopore across the membrane. The nanopore was generated when the measured current in this system exceeds the preset value.

\section{(4) Graphene}

Recently, advancements on fabricating graphene nanopores were reported [130-132]. Using electron beam writing, graphene nanopores with diameters less than $5 \mathrm{~nm}$ were achieved [131,133]. Besides the traditional electron beam writing method, Deng et al. [134] proposed a technique of fabricating a graphene nanopore of $5 \mathrm{~nm}$ in diameter with a helium ion microscope (HIM). For this method, there is a trimer to emit the helium ion beam under a high voltage at the top of an emitter. Under the action of the $\mathrm{He}^{+}$ion, a graphene nanopore can be obtained. In that paper, they demonstrated a precise control of nanopore size and shape during the manufacturing process by controlling the dwell time of exposures.

\subsection{PDMS Nanochannels}

Nanochannels can be fabricated both in polymer and glass substrates. The two major advantages of using these nanochannels are being an integral part in a complex fluidic structure and allowing optical access to objects transported inside the channels. Fabricating a PDMS nanochannel is more attractive due to the distinctive advantage of PDMS in developing microfluidic and nanofluidic devices. Generally, a mold or master is needed for PDMS replica. Such a mold is normally fabricated by methods of the electron beam lithography (EBL) [135-141] and focused ion beam (FIB) [142-149]. For these two methods, the wavelength of the e-beam has a vital influence on the resolution of the nanochannel. However, the equipment is very expensive and not every lab can afford it [150].

To develop a simpler and reliable PDMS nanochannel fabrication method, Peng and Li [151] reported fabricating a single nanocrack on a polymer substrate by using a solvent-induced technique (Figure 6). The minimal dimension of the nanocracks could reach nearly $64 \mathrm{~nm}$ in width and $17.4 \mathrm{~nm}$ in depth. Using this method, a PDMS nanochannel with a width of about $100 \mathrm{~nm}$ was fabricated [152]. The key procedure of this fabrication technique is the making of nanocracks firstly. The next step is to employ the soft lithography technique (SU8 photoresist) to copy this nanochannel mold. At last, the smooth cast slab is solidified and nanoimprinted by pressure gauge. 
(a1)

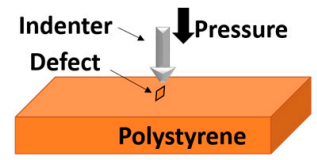

(a3)

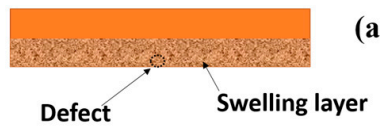

SU8 photoresist

(b1)

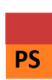

(b2)

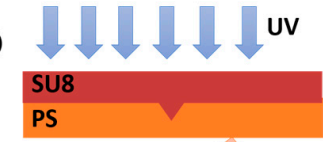

(d)

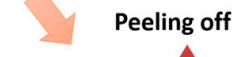

(c2)

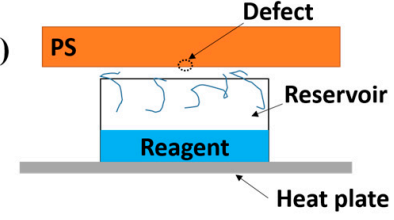

(a4)

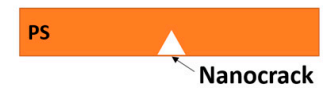

Solidifying Smooth cast

(c1)

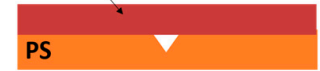

【III

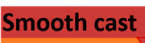

PS

Positive nanohannel mold

X-PDMS

(e)

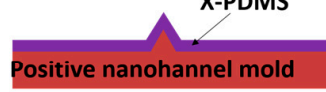

(f)

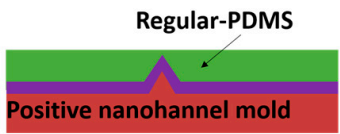

(h)

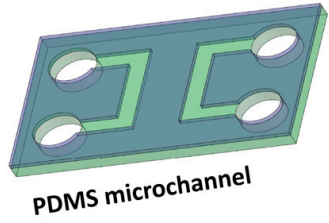

(g)

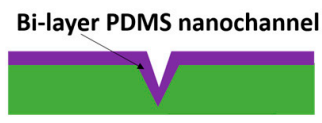

(i)

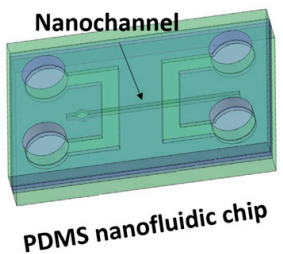

Figure 6. Procedures for polydimethylsiloxane (PDMS) nanochannel fabrication by using a solvent-induced nanocrack. (a1) making microdefects on a polystyrene slab by using an indenter of a micro-hardness testing system; (a2) absorption of the solvent; (a3) swelling of the polystyrene surface and initialization of nanocracks; (a4) nanocracks on the polystyrene surface. (b1) spin-coating of SU8 photoresist on the polystyrene slab with nanocracks; (b2) exposure the SU-8 layer to UV light. (c1) fabricating of solidifying smooth cast slab; (c2) nanoimprint by using a pressure gauge. (d)-(i) Show how to make a PDMS micro-nanofluidic chip by using the nanochannel mold: (d) nanochannel mold after peeling off process; (e) coating of x-PDMS on the nanochannel mold; (f) casting another layer of regular PDMS on the x-PDMS; (g) bi-layer PDMS nanochannel; (h) fabrication of bi-layer microchannel system; (i) PDMS micro-nanofluidic chip after bonding.

\section{Outlook}

The latest development of microfuidic and nanofluidic RPS technologies within the last 6 years is reviewed in this paper. Some new and important phenomena both in microscale and nanoscale have been discovered, which greatly enriches the power of the Coulter principle. Researches on micro- and nano-RPS, both from the aspects of theory and application, still have many challenges and great potential. For example, one big question is the mathematic relationship between the resistance change and the sizes of a particle and a sensing channel at nanoscale, especially when the EDLs of the sensing channel are overlapped. Another challenge which prevents the wide application of the 
nano-RPS system is the integration of a microchannel with the nanochannel. While there are variety of nanochannel fabrication methods, as reviewed above, difficulties still exist for the integration of a nanochannel with a microchannel. Simple and reliable integration technology can greatly benefit both fundamental and applied research.

Acknowledgments: The authors wish to thank the financial support of National Science Foundation program of China (51679023) and 863 plan (2015AA020409) to Yongxin Song, the Natural Sciences and Engineering Research Council of Canada through a research grant to Dongqing Li, the support from Fundamental Research Funds for the Central Universities (3132016325 and 3132017012) and from the University 111 project of China under Grant No. B08046 is greatly appreciated.

Conflicts of Interest: The authors declare no conflict of interest.

\section{References}

1. Wang, Z.; Wang, X.; Liu, S.; Yin, J.; Wang, H. Fluorescently imaged particle counting immunoassay for sensitive detection of DNA modifications. Anal. Chem. 2010, 82, 9901-9908. [PubMed]

2. Barnard, J.G.; Singh, S.; Randolph, T.W.; Carpenter, J.F. Subvisible particle counting provides a sensitive method of detecting and quantifying aggregation of monoclonal antibody caused by freeze-thawing: Insights into the roles of particles in the protein aggregation pathway. J. Pharm. Sci. 2011, 100, 492-503. [PubMed]

3. Benech, H.; Théodoro, F.; Herbet, A.; Page, N.; Schlemmer, D.; Pruvost, A. Peripheral blood mononuclear cell counting using a DNA-detection-based method. Anal. Chem. 2004, 330, 172-174.

4. Huang, B.; Wu, H.K.; Bhaya, D.; Grossman, A.; Granier, S.; Kobilka, B.K.; Zare, R.N. Counting low-copy number proteins in a single cell. Science 2007, 315, 81-84. [PubMed]

5. Amann, R.I.; Binder, B.J.; Olson, R.J.; Chisholm, S.W.; Devereux, R.; Stahl, D.A. Combination of $16 \mathrm{~S}$ rRNA-targeted oligonucleotide probes with flow cytometry for analyzing mixed microbial populations. Appl. Environ. Microbiol. 1990, 56, 1919-1925. [PubMed]

6. Yarnell, J.W.; Baker, I.A.; Sweetnam, P.M.; Bainton, D.; O’Brien, J.R.; Whitehead, P.J.; Elwood, P.C. Fibrinogen, viscosity, and white blood cell count are major risk factors for ischemic heart disease. Circulation 1991, 83, 836-844. [PubMed]

7. Brüllmann, D.; Pabst, A.; Lehmann, K.; Ziebart, T.; Klein, M.; d'Hoedt, B. Counting touching cell nuclei using fast ellipse detection to assess in vitro cell characteristics: A feasibility study. Clin. Oral Investig. 2012, 16, 33-38. [PubMed]

8. Braun, S.; Marth, C. Circulating tumor cells in metastatic breast cancer-Toward individualized treatment. N. Engl. J. Med. 2004, 351, 824-826. [PubMed]

9. Adams, A.A.; Okagbare, P.I.; Feng, J.; Hupert, M.L.; Patterson, D.; Göttert, J.; McCarley, R.L.; Nikitopoulos, D.; Murphy, M.C.; Soper, S.A. Highly efficient circulating tumor cell isolation from whole blood and label-free enumeration using polymer-based microfluidics with an integrated conductivity sensor. J. Am. Chem. Soc. 2008, 30, 8633-8641.

10. Cristofanilli, M.; Budd, G.T.; Ellis, M.J.; Stopeck, A.; Matera, J.; Miller, M.C.; Reuben, J.M.; Doyle, G.V.; Allard, W.J.; Terstappen, L.W.M.M.; et al. Circulating tumor cells, disease progression, and survival in metastatic breast cancer. N. Engl. J. Med. 2004, 351, 781-791. [PubMed]

11. Pantel, K.; Riethdorf, S. Are circulating tumor cells predictive of overall survival? Nat. Rev. Clin. Oncol. 2009, 6, 190-191. [CrossRef] [PubMed]

12. Slade, M.J.; Coombes, R.C. The clinical significance of disseminated tumor cells in breast cancer. Nat. Rev. Clin. Oncol. 2007, 4, 30-41. [CrossRef] [PubMed]

13. Zhang, H.; Chan, H.C.; Pan, X.; Li, D. Methods for counting particles in microfluidic applications. Microfluid. Nanofluid. 2009, 7, 739-749. [CrossRef]

14. Wallace, H.C. Means for Counting Particles Suspended in a Fluid. U.S. Patent 2,656,508, 20 October 1953.

15. Saleh, O.A.; Sohn, L.L. Direct Detection of Antibody-Antigen Binding Using an On-Chip Artificial Pore. Proc. Natl. Acad. Sci. USA 2003, 100, 820-824. [CrossRef] [PubMed]

16. Sam, E.; Mehdi, J.; Robert, W.; Duttonand, R.W.; Davis, J.M.; Dutton, R.W.; Davis, A.R.W. Smart surfaces: Use of electrokinetics for selective modulation of biomolecular affinities. MRS Online Proc. Libr. 2012, 1415, 153-158. 
17. Sam, E.; Mehdi, J.; Dutton, R.W.; Davis, R.W. Microfluidic diagnostic tool for the developing world: Contactless impedance flowcytometry. Lab Chip 2012, 12, 4499-4507.

18. Sam, E.; Mehdi, J.; Dutton, R.W.; Davis, R.W. Smart surface forelution of protein-protein bound particles: Nanonewton dielectrophoretic forces using atomic layer deposited oxides. Anal. Chem. 2012, 84, 10793-10801.

19. Mehdi, J.; Sam, E.; Dutton, R.W.; Davis, R.W. Use of negative dielectrophoresis for selective elution of protein-bound particles. Anal. Chem. 2012, 84, 1432-1438.

20. Mehdi, J.; Davis, R.W. A microfluidic platform for electrical detection of DNA hybridization. Sens. Actuators B Chem. 2011, 154, 22-27.

21. Davey, H.M; Kell, D.B. Flow cytometry and cell sorting of heterogeneous microbial populations: The importance of single-cell analyses. Microbiol. Rev. 1996, 60, 641-696. [PubMed]

22. Shapiro, H.M. The evolution of cytometers. Cytometry Part A 2004, 58A, 13-20. [CrossRef] [PubMed]

23. Moldavan, A. Photo-electric technique for the counting of microscopical cells. Science 1934, 80, 188-189. [CrossRef] [PubMed]

24. Manz, A.; Harrison, D.J.; Verpoorte, E.M.J.; Fettinger, J.C.; Paulus, A.; Lüdi, H. Planar chips technology for miniaturization and integration of separation techniques into monitoring systems: Capillary electrophoresis on a chip. J. Chromatogr. A 1992, 593, 253-258. [CrossRef]

25. Whitesides, G.M.; Stroock, A.D. Flexible methods for microfluidics. Phys. Today 2001, 54, 42-48. [CrossRef]

26. Quake, S. The chips are down-Microfluidic large-scale integration. TrAC Trends Anal. Chem. 2002, 21, 12-13.

27. Beebe, D.J.; Mensing, G.A.; Walker, G.M. Physics and applications of microfluidics in biology. Annu. Rev. Biomed. Eng. 2002, 4, 261-286. [CrossRef] [PubMed]

28. Stone, H.A.; Stroock, A.D.; Ajdari, A. Engineering flows in small devices: Microfluidics toward a lab-on-a-chip. Annu. Rev. Fluid Mech. 2004, 36, 381-411. [CrossRef]

29. Squires, T. Microfluidics: Fluid physics at the nanoliter scale. Rev. Mod. Phys. 2005, 77, 977-1026. [CrossRef]

30. Whitesides, G.M. The origins and the future of microfluidics. Nature 2006, 442, 368-373. [CrossRef] [PubMed]

31. Zheng, S.; Liu, M.; Tai, Y.C. Micro coulter counters with platinum black electroplated electrodes for human blood cell sensing. Biomed. Microdevices 2008, 10, 221-231. [CrossRef] [PubMed]

32. Jagtiani, A.V.; Carletta, J.; Zhe, J. An impedimetric approach for accurate particle sizing using a microfluidic Coulter counter. J. Micromech. Microeng. 2011, 21, 045036. [CrossRef]

33. Richards, A.L.; Dickey, M.D.; Kennedy, A.S. Design and demonstration of a novel micro-Coulter counter utilizing liquid metal electrodes. J. Micromech. Microeng. 2012, 22, 115012. [CrossRef]

34. Gawad, S.; Cheung, K.; Seger, U.; Bertsch, A.; Renaud, P. Dielectric spectroscopy in a micromachined flow cytometer: theoretical and practical considerations. Lab Chip 2004, 4, 241-251. [CrossRef] [PubMed]

35. Gawad, S.; Schild, L.; Renaud, P.H. Micromachined impedance spectroscopy flow cytometer for cell analysis and particle sizing. Lab Chip 2001, 1, 76-82. [CrossRef] [PubMed]

36. Rodriguez-Trujillo, R.; Mills, C.A.; Samitier, J.; Gomila, G. Low cost micro-coulter counter with hydrodynamic focusing. Microfluid. Nanofluid. 2007, 3, 171-176. [CrossRef]

37. Jagtiani, A.V.; Carletta, J.; Zhe, J. A microfluidic multichannel resistive pulse sensor using frequency division multiplexing for high throughput counting of micro particles. J. Micromech. Microeng. 2011, 21, 065004. [CrossRef]

38. Clerk, M.J. Treatise on Electricity and Magnetism; Clarendon Press: Oxford, UK, 1904.

39. Deblois, R.W.; Bean, C.P. Counting and sizing of submicron particles by the resistive pulse technique. Rev. Sci. Instrum. 1970, 41, 909-916. [CrossRef]

40. Smythe, W.R. Flow around a spheroid in a circular tube. Phys. Fluids 1964, 7, 633-638. [CrossRef]

41. Deblois, R.W.; Bean, C.P.; Wesley, R.K.A. Electrokinetic measurements with submicron particles and pores by the resistive pulse technique. J. Colloid Interface Sci. 1977, 61, 323-335. [CrossRef]

42. Gregg, E.C.; Steidley, K.D. Electrical counting and sizing of mammalian cells in suspension. Biophys. J. 1965, 5, 393-405. [CrossRef]

43. Saleh, O.A. A Novel Resistive Pulse Sensor for Biological Measurements. Ph.D. Thesis, Princeton University, Princeton, NJ, USA, January 2003.

44. Weatherall, E.; Willmott, G.R. Conductive and Biphasic Pulses in Tunable Resistive Pulse Sensing. J. Phys. Chem. B 2015, 119, 5328-5335. [CrossRef] [PubMed]

45. Menestrina, J.; Yang, C.; Schiel, M. Charged Particles Modulate Local Ionic Concentrations and Cause Formation of Positive Peaks in Resistive-Pulse-Based Detection. J. Phys. Chem. C 2014, 118, 2391-2398. [CrossRef] 
46. Stober, G.; Steinbock, L.J.; Keyser, U.F. Modeling of colloidal transport in capillaries. J. Appl. Phys. 2009, 104, 084702. [CrossRef]

47. Steinbock, L.J.; Stober, G.; Keyser, U.F. Sensing DNA-coatings of microparticles using micropipettes. Biosens. Bioelectron. 2009, 24, 2423-2427. [CrossRef] [PubMed]

48. Davenport, M.; Healy, K.; Pevarnik, M.; Teslich, N.; Cabrini, S.; Morrison, A.P. The role of pore geometry in single nanoparticle detection. ACS Nano 2012, 6, 8366-8380. [CrossRef] [PubMed]

49. Tsutsui, M.; Hongo, S.; He, Y.; Taniguchi, M.; Gemma, N.; Kawai, T. Single-nanoparticle detection using a low-aspect-ratio pore. ACS Nano 2012, 6, 3499-3505. [CrossRef] [PubMed]

50. Carson, S.; Wilson, J.; Aksimentiev, A.; Wanunu, M. Smooth DNA transport through a narrowed pore geometry. Biophys. J. 2014, 107, 2381-2393. [CrossRef] [PubMed]

51. Sahebi, M.; Azimian, A.R. Effect of some geometrical characteristics of asymmetric nanochannels on acceleration-driven flow. Microfluid. Nanofluid. 2015, 18, 1-9. [CrossRef]

52. Kaya, D.; Dinler, A.; San, N.; Kececi, K. Effect of Pore Geometry on Resistive-Pulse Sensing of DNA Using Track-Etched PET Nanopore Membrane. Electrochim. Acta 2016, 202, 157-165. [CrossRef]

53. Liu, J.; Kvetny, M.; Feng, J.; Wang, D.; Wu, B.; Brown, W. Surface charge density determination of single conical nanopores based on normalized ion current rectification. Langmuir 2012, 28, 1588-1595. [CrossRef] [PubMed]

54. Weatherall, E.; Hauer, P.; Vogel, R.; Willmott, G.R. Pulse Size Distributions in Tunable Resistive Pulse Sensing. Anal. Chem. 2016, 88, 8648-8656. [CrossRef] [PubMed]

55. Platt, M.; Willmott, G.R.; Lee, G.U. Resistive pulse sensing of analyte-induced multicomponent rod aggregation using tunable pores. Small 2012, 8, 2436-2444. [CrossRef] [PubMed]

56. Lee, C.; Chen, C. Characterizations of nanospheres and nanorods using resistive-pulse sensing. Microsyst. Technol. 2017, 23, 299-304. [CrossRef]

57. Song, Y.; Wang, C.; Sun, R. Effect of induced surface charge of metal particles on particle sizing by resistive pulse sensing technique. J. Colloid Interface Sci. 2014, 423, 20-24. [CrossRef] [PubMed]

58. Liu, R.; Wang, N.; Kamili, F.; Sarioglu, A.F. Microfluidic CODES: A scalable multiplexed electronic sensor for orthogonal detection of particles in microfluidic channels. Lab Chip 2016, 16, 1350-1357. [CrossRef] [PubMed]

59. Song, Y.; Yang, J.; Pan, X.; Li, D. High-throughput and sensitive particle counting by a novel microfluidic differential resistive pulse sensor with multidetecting channels and a common reference channel. Electrophoresis 2015, 36, 495-501. [CrossRef] [PubMed]

60. Castillo-Fernandez, O.; Rodriguez-Trujillo, R.; Gomila, G.; Samitier, J. High-speed counting and sizing of cells in an impedance flow microcytometer with compact electronic instrumentation. Microfluid. Nanofluid. 2014, 16, 91-99. [CrossRef]

61. Choi, H.; Jeon, C.S.; Hwang, I.; Ko, J.; Lee, S.; Choo, J.; Chung, T.D. A flow cytometry-based submicron-sized bacterial detection system using a movable virtual wall. Lab Chip 2014, 14, 2327-2333. [CrossRef] [PubMed]

62. Bernabini, C.; Holmes, D.; Morgan, H. Micro-impedance cytometry for detection and analysis of micron-sized particles and bacteria. Lab Chip 2011, 11, 407-412. [CrossRef] [PubMed]

63. Liu, Z.; Li, J.; Yang, J.; Song, Y.; Pan, X.; Li, D. Improving particle detection sensitivity of a microfluidic resistive pulse sensor by a novel electrokinetic flow focusing method. Microfluid. Nanofluid. 2017, $21,4$. [CrossRef]

64. Kasianowicz, J.J.; Brandin, E.; Branton, D.; Deamer, D.W. Characterization of individual polynucleotide molecules using a membrane channel. Proc. Natl. Acad. Sci. USA 1966, 93, 13770-13773. [CrossRef]

65. Kozak, D.; Anderson, W.; Vogel, R.; Trau, M. Advances in resistive pulse sensors: Devices bridging the void between molecular and microscopic detection. Nano Today 2011, 6, 531-545. [CrossRef] [PubMed]

66. Harrer, S.; Kim, S.C.; Schieber, C.; Kannam, S.; Gunn, N.; Moore, S. Label-free screening of single biomolecules through resistive pulse sensing technology for precision medicine applications. Nanotechnology 2015, 26, 182502. [CrossRef] [PubMed]

67. Billinge, E.R.; Broom, M.; Platt, M. Monitoring aptamer-protein interactions using tunable resistive pulse sensing. Anal. Chem. 2014, 86, 1030-1037. [CrossRef] [PubMed]

68. Sha, J.; Hasan, T.; Milana, S.; Bertulli, C.; Bell, N.A.; Privitera, G.; Keyser, U.F. Nanotubes complexed with DNA and proteins for resistive-pulse sensing. ACS Nano 2013, 7, 8857-8869. [CrossRef] [PubMed]

69. Blundell, E.L.; Vogel, R.; Platt, M. Particle charge analysis of DNA-modified nanoparticles using tunable resistive pulse sensing. Langmuir 2016, 32, 1082-1090. [CrossRef] [PubMed] 
70. Yang, A.K.L.; Lu, H.; Wu, S.Y.; Kwok, H.C.; Ho, H.P.; Yu, S.; Kong, S.K. Detection of Panton-Valentine Leukocidin DNA from methicillin-resistant Staphylococcus aureus by resistive pulse sensing and loop-mediated isothermal amplification with gold nanoparticles. Anal. Chim. Acta 2013, 782, 46-53. [CrossRef] [PubMed]

71. Booth, M.A.; Vogel, R.; Curran, J.M.; Harbison, S.; Travas-Sejdic, J. Detection of target-probe oligonucleotide hybridization using synthetic nanopore resistive pulse sensing. Biosens. Bioelectron. 2013, 45, 136-140. [CrossRef] [PubMed]

72. Sheng, T.H.; Ling, F.Y.; Li, N.B.; Hong, Q.L. An ultrasensitive and selective fluorescence assay for sudan $\mathrm{i}$ and iii against the influence of sudan ii andiv. Biosens. Bioelectron. 2013, 42, 136-140.

73. Kühnemund, M.; Nilsson, M. Digital quantification of rolling circle amplified single DNA molecules in a resistive pulse sensing nanopore. Biosens. Bioelectron. 2015, 67, 11-17. [CrossRef] [PubMed]

74. Traversi, F.; Raillon, C.; Benameur, S.M.; Liu, K.; Khlybov, S.; Tosun, M. Detecting the translocation of DNA through a nanopore using graphene nanoribbons. Nat. Nanotechnol. 2013, 8, 939-945. [CrossRef] [PubMed]

75. Hernándezainsa, S.; Bell, N.A.; Thacker, V.V.; Göpfrich, K.; Misiunas, K.; Fuentesperez, M.E. DNA origami nanopores for controlling DNA translocation. ACS Nano 2013, 7, 6024-6030. [CrossRef] [PubMed]

76. Sischka, A.; Galla, L.; Meyer, A.J.; Spiering, A.; Knust, S.; Mayer, M. Controlled translocation of DNA through nanopores in carbon nano-, silicon-nitride- and lipid-coated membranes. Analyst 2015, 140, 4843-4847. [CrossRef] [PubMed]

77. Rodriguez-Trujillo, R.; Ajine, M.A.; Orzan, A.; Mar, M.D.; Larsen, F.; Clausen, C.H. Label-free protein detection using a microfluidic coulter-counter device. Sens. Actuators B Chem. 2014, 190, 922-927. [CrossRef]

78. Cai, H.; Wang, Y.; Yu, Y.; Mirkin, M.V.; Bhakta, S.; Bishop, G.W.; Rusling, J.F. Resistive-pulse measurements with nanopipettes: Detection of vascular endothelial growth factor C (VEGF-C) using antibody-decorated nanoparticles. Anal. Chem. 2015, 87, 6403-6410. [CrossRef] [PubMed]

79. Han, Y.; Wu, H.; Liu, F.; Cheng, G.; Zhe, J. Novel quantitative macro biomolecule analysis based on a micro coulter counter. Anal. Chem. 2014, 86, 9717-9722. [CrossRef] [PubMed]

80. Takakura, T.; Yanagi, I.; Goto, Y.; Ishige, Y.; Kohara, Y. Single-molecule detection of proteins with antigen-antibody interaction using resistive-pulse sensing of submicron latex particles. Appl. Phys. Lett. 2016, 108, 123701. [CrossRef]

81. Vogel, R.; Willmott, G.; Kozak, D.; Roberts, G.S.; Anderson, W.; Groenewegen, L.; Glossop, B.; Barnett, A.; Turner, A.; Trau, M. Quantitative sizing of nano/microparticles with a tunable elastomeric pore sensor. Anal. Chem. 2011, 83, 3499-3506. [CrossRef] [PubMed]

82. Roberts, G.S.; Yu, S.; Zeng, Q.; Chan, L.C.L.; Anderson, W.; Colby, A.H.; Grinstaff, M.W.; Reid, S.; Vogel, R. Tunable pores for measuring concentrations of synthetic and biological nanoparticle dispersions. Biosens. Bioelectron. 2012, 31, 17-25. [CrossRef] [PubMed]

83. Colby, A.H.; Colson, Y.L.; Grinstaff, M.W. Microscopy and tunable resistive pulse sensing characterization of the swelling of $\mathrm{pH}$ responsive, polymeric expansile nanoparticles. Nanoscale 2013, 5, 3496-3504. [CrossRef] [PubMed]

84. Fraikin, J.L.; Teesalu, T.; Mckenney, C.M.; Ruoslahti, E.; Cleland, A.N. A high-throughput label-free nanoparticle analyser. Nat. Nanotechnol. 2011, 6, 308-313. [CrossRef] [PubMed]

85. Pal, A.K.; Aalaei, I.; Gadde, S.; Gaines, P.; Schmidt, D.; Demokritou, P.; Bello, D. High Resolution Characterization of Engineered Nanomaterial Dispersions in Complex Media Using Tunable Resistive Pulse Sensing Technology. ACS Nano 2014, 8, 9003-9015. [CrossRef] [PubMed]

86. Luo, L.; German, S.; Lan, W.; Holden, D.; Mega, T.; White, H. Resistive-Pulse Analysis of Nanoparticles. Annu. Rev. Anal. Chem. 2014, 7, 513-535. [CrossRef] [PubMed]

87. Sikora, A.; Shard, A.G.; Minelli, C. Size and $\zeta$-potential measurement of silica nanoparticles in serum using tunable resistive pulse sensing. Langmuir 2016, 32, 2216-2224. [CrossRef] [PubMed]

88. Arjmandi, N.; Roy, W.V.; Lagae, L.; Borghs, G. Measuring the electric charge and zeta potential of nanometer-sized objects using pyramidal-shaped nanopores. Anal. Chem. 2012, 84, 8490-8496. [CrossRef] [PubMed]

89. Eldridge, J.A.; Willmott, G.R.; Anderson, W.; Vogel, R. Nanoparticle ל-potential measurements using tunable resistive pulse sensing with variable pressure. J. Colloid Interface Sci. 2014, 429, 45-52. [CrossRef] [PubMed] 
90. Somerville, J.A.; Willmott, G.R.; Eldridge, J.; Griffiths, M.; McGrath, K.M. Size and charge characterisation of a submicrometre oil-in-water emulsion using resistive pulse sensing with tunable pores. J. Colloid Interface Sci. 2013, 394, 243-251. [CrossRef] [PubMed]

91. Vogel, R.; Anderson, W.; Eldridge, J.; Glossop, B.; Willmott, G. A variable pressure method for characterizing nanoparticle surface charge using pore sensors. Anal. Chem. 2012, 84, 3125-3131. [CrossRef] [PubMed]

92. Kozak, D.; Anderson, W.; Vogel, R.; Chen, S.; Antaw, F.; Trau, M. Simultaneous Size and zeta-Potential Measurements of Individual Nanoparticles in Dispersion Using Size-Tunable Pore Sensors. ACS Nano 2012, 6, 6990-6997. [CrossRef] [PubMed]

93. Dekker, C. Solid-state nanopores. Nat. Nanotechnol. 2007, 2, 209-215. [CrossRef] [PubMed]

94. Howorka, S.; Siwy, Z. Nanopore analytics: Sensing of single molecules. Chem. Soc. Rev. 2009, 38, $2360-2384$. [CrossRef] [PubMed]

95. Venkatesan, B.; Bashir, R. Nanopore sensors for nucleic and acid analysis. Nat. Nanotechnol. 2011, 6, 615-624. [CrossRef] [PubMed]

96. Chen, J.T.; Wei, T.H.; Chang, C.W.; Ko, H.W.; Chu, C.W.; Chi, M.H.; Tsai, C.C. Fabrication of polymer nanopeapods in the nanopores of anodic aluminum oxide templates using a double-solution wetting method. Macromolecules 2014, 47, 5227-5235. [CrossRef]

97. Nasir, S.; Ali, M.; Ramirez, P.; Gómez, V.; Oschmann, B.; Muench, F.; Ensinger, W. Fabrication of Single Cylindrical Au-Coated Nanopores with Non-Homogeneous Fixed Charge Distribution Exhibiting High Current Rectifications. ACS Appl. Mater. Interfaces 2014, 6, 12486-12494. [CrossRef] [PubMed]

98. Bandara, Y.N.D.; Karawdeniya, B.I.; Dwyer, J.R. Real-Time Profiling of Solid-State Nanopores During Solution-Phase Nanofabrication. ACS Appl. Mater. Interfaces 2016, 8, 30583-30589. [CrossRef] [PubMed]

99. Lan, W.J.; Holden, D.A.; Zhang, B.; White, H.S. Nanoparticle transport in conical-shaped nanopores. Anal. Chem. 2011, 83, 3840-3847. [CrossRef] [PubMed]

100. Li, J.; Li, C.; Gao, X. Structural evolution of self-ordered alumina tapered nanopores with $100 \mathrm{~nm}$ interpore distance. Appl. Surf. Sci. 2011, 257, 10390-10394. [CrossRef]

101. Wei, R.; Pedone, D.; Zürner, A.; Döblinger, M.; Rant, U. Fabrication of metallized nanopores in silicon nitride membranes for single-molecule sensing. Small 2010, 6, 1406-1414. [CrossRef] [PubMed]

102. Sheng, Q.; Wang, L.; Wang, C.; Wang, X.; Xue, J. Fabrication of nanofluidic diodes with polymer nanopores modified by atomic layer deposition. Biomicrofluidics 2014, 8, 052111. [CrossRef] [PubMed]

103. Song, L.; Hobaugh, M.R.; Shustak, C.; Cheley, S.; Bayley, H.; Gouaux, J.E. Structure of staphylococcal $\alpha$-hemolysin, a heptameric transmembrane pore. Science 1996, 274, 1859-1865. [CrossRef] [PubMed]

104. Yusko, E.C.; Johnson, J.M.; Majd, S.; Prangkio, P.; Rollings, R.C.; Li, J.; Mayer, M. Controlling protein translocation through nanopores with bio-inspired fluid walls. Nat. Nanotechnol. 2011, 6, 253-260. [CrossRef] [PubMed]

105. Göpfrich, K.; Kulkarni, C.V.; Pambos, O.J.; Keyser, U.F. Lipid nanobilayers to host biological nanopores for DNA translocations. Langmuir 2012, 29, 355-364. [CrossRef] [PubMed]

106. Hemmler, R.; Böse, G.; Wagner, R.; Peters, R. Nanopore unitary permeability measured by electrochemical and optical single transporter recording. Biophys. J. 2005, 88, 4000-4007. [CrossRef] [PubMed]

107. Pastoriza-Gallego, M.; Rabah, L.; Gibrat, G.; Thiebot, B.; van der Goot, F.G.; Auvray, L.; Pelta, J. Dynamics of unfolded protein transport through an aerolysin pore. J. Am. Chem. Soc. 2011, 133, 2923-2931. [CrossRef] [PubMed]

108. Yilun, Y.; Xing, Z.; Yu, L.; Mengzhu, X.; Honglin, L.; Yitao, L. Single molecule study of the weak biological interactions between p53 and DNA. Acta Chim. Sin. 2013, 71, 44-50.

109. Mohammad, M.M.; Raghuvaran Iyer, K.R.H.; McPike, M.P.; Borer, P.N.; Movileanu, L. Engineering a rigid protein tunnel for biomolecular detection. J. Am. Chem. Soc. 2012, 134, 9521-9531. [CrossRef] [PubMed]

110. Niedzwiecki, D.J.; Mohammad, M.M.; Movileanu, L. Inspection of the engineered fhua $\delta \mathrm{c} / \delta 41$ protein nanopore by polymer exclusion. Biophys. J. 2012, 103, 2115-2124. [CrossRef] [PubMed]

111. Soskine, M.; Biesemans, A.; Moeyaert, B.; Cheley, S.; Bayley, H.; Maglia, G. An engineered ClyA nanopore detects folded target proteins by selective external association and pore entry. Nano Lett. 2012, 12, 4895-4900. [CrossRef] [PubMed]

112. Ying, Y.L.; Li, D.W.; Liu, Y.; Dey, S.K.; Kraatz, H.B.; Long, Y.T. Recognizing the translocation signals of individual peptide-oligonucleotide conjugates using an $\alpha$-hemolysin nanopore. Chem. Commun. 2012, 48, 8784-8786. [CrossRef] [PubMed] 
113. Singh, P.R.; Bárcena-Uribarri, I.; Modi, N.; Kleinekathöfer, U.; Benz, R.; Winterhalter, M.; Mahendran, K.R. Pulling peptides across nanochannels: Resolving peptide binding and translocation through the hetero-oligomeric channel from nocardia farcinica. ACS Nano 2012, 6, 10699-10707. [CrossRef] [PubMed]

114. Kudr, J.; Skalickova, S.; Nejdl, L.; Moulick, A.; Ruttkay-Nedecky, B.; Adam, V.; Kizek, R. Fabrication of solid-state nanopores and its perspectives. Electrophoresis 2015, 36, 2367-2379. [CrossRef] [PubMed]

115. Sha, J.; Si, W.; Xu, W.; Zou, Y.; Chen, Y. Glass capillary nanopore for single molecule detection. Sci. China Technol. Sci. 2015, 58, 803-812. [CrossRef]

116. Steinbock, L.J.; Otto, O.; Chimerel, C.; Gornall, J.; Keyser, U.F. Detecting DNA folding with nanocapillaries. Nano Lett. 2010, 10, 2493-2497. [CrossRef] [PubMed]

117. Steinbock, L.J.; Bulushev, R.D.; Krishnan, S.; Raillon, C.; Radenovic, A. DNA translocation through low-noise glass nanopores. ACS Nano 2013, 7, 11255-11262. [CrossRef] [PubMed]

118. Cai, S.L.; Cao, S.H.; Zheng, Y.B.; Zhao, S.; Yang, J.L.; Li, Y.Q. Surface charge modulated aptasensor in a single glass conical nanopore. Biosens. Bioelectron. 2015, 71, 37-43. [CrossRef] [PubMed]

119. He, H.; Xu, X.; Wang, P.; Chen, L.; Jin, Y. The facile surface chemical modification of a single glass nanopore and its use in the nonenzymatic detection of uric acid. Chem. Commun. 2015, 51, 1914-1917. [CrossRef] [PubMed]

120. Bafna, J.A.; Soni, G.V. Fabrication of low noise borosilicate glass nanopores for single molecule sensing. PLoS ONE 2016, 11, e0157399. [CrossRef] [PubMed]

121. Ali, M.; Yameen, B.; Neumann, R.; Ensinger, W.; Knoll, W.; Azzaroni, O. Biosensing and supramolecular bioconjugation in single conical polymer nanochannels. Facile incorporation of biorecognition elements into nanoconfined geometries. J. Am. Chem. Soc. 2008, 130, 16351-16357. [CrossRef] [PubMed]

122. Wang, J.; Martin, C.R. A new drug-sensing paradigm based on ion-current rectification in a conically shaped nanopore. Nanomedicine 2008, 3, 13-20. [CrossRef] [PubMed]

123. Chavan, V.; Agarwal, C.; Pandey, A.K.; Nair, J.P.; Surendran, P.; Kalsi, P.C.; Goswami, A. Controlled development of pores in polyethylene terepthalate sheet by room temperature chemical etching method. J. Membr. Sci. 2014, 471, 185-191. [CrossRef]

124. Venta, K.; Shemer, G.; Puster, M.; Rodriguez-Manzo, J.A.; Balan, A.; Rosenstein, J.K.; Drndić, M. Differentiation of short single-stranded DNA homopolymers in solid-state nanopores. ACS Nano 2013, 7, 4629-4636. [CrossRef] [PubMed]

125. Zhang, M.; Schmidt, T.; Sangghaleh, F.; Roxhed, N.; Sychugov, I.; Linnros, J. Oxidation of nanopores in a silicon membrane: Self-limiting formation of sub-10 nm circular openings. Nanotechnology 2014, 25, 355302. [CrossRef] [PubMed]

126. Balme, S.; Coulon, P.E.; Lepoitevin, M.; Charlot, B.; Yandrapalli, N.; Favard, C.; Janot, J.M. Influence of Adsorption on Proteins and Amyloid Detection by Silicon Nitride Nanopore. Langmuir 2016, 32, 8916-8925. [CrossRef] [PubMed]

127. Kwok, H.; Briggs, K.; Tabard-Cossa, V. Nanopore fabrication by controlled dielectric breakdown. PLoS ONE 2014, 9, e92880. [CrossRef] [PubMed]

128. Briggs, K.; Kwok, H.; Tabard-Cossa, V. Automated Fabrication of 2-nm Solid-State Nanopores for Nucleic Acid Analysis. Small 2014, 10, 2077-2086. [CrossRef] [PubMed]

129. Yanagi, I.; Akahori, R.; Hatano, T.; Takeda, K.I. Fabricating nanopores with diameters of sub-1 nm to $3 \mathrm{~nm}$ using multilevel pulse-voltage injection. Sci. Rep. 2014, 4, 5000. [CrossRef] [PubMed]

130. Kumar, A.; Park, K.B.; Kim, H.M.; Kim, K.B. Noise and its reduction in graphene based nanopore devices. Nanotechnology 2013, 24, 495503. [CrossRef] [PubMed]

131. Fox, D.S.; Maguire, P.; Zhou, Y.; Rodenburg, C.; O’Neill, A.; Coleman, J.N.; Zhang, H. Sub-5 nm graphene nanopore fabrication by nitrogen ion etching induced by a low-energy electron beam. Nanotechnology 2016, 27, 195302. [CrossRef] [PubMed]

132. Jung, W.; Kim, J.; Kim, S.; Park, H.G.; Jung, Y.; Han, C.S. A Novel Fabrication of 3.6 nm High Graphene Nanochannels for Ultrafast Ion Transport. Adv. Mater. 2017, 29, 1605854. [CrossRef] [PubMed]

133. Goyal, G.; Lee, Y.B.; Darvish, A.; Ahn, C.W.; Kim, M.J. Hydrophilic and size-controlled graphene nanopores for protein detection. Nanotechnology 2016, 27, 495301. [CrossRef] [PubMed]

134. Deng, Y.; Huang, Q.; Zhao, Y.; Zhou, D.; Ying, C.; Wang, D. Precise fabrication of a $5 \mathrm{~nm}$ graphene nanopore with a helium ion microscope for biomolecule detection. Nanotechnology 2016, 28, 045302. [CrossRef] [PubMed]

135. Perry, J.M.; Zhou, K.; Harms, Z.D.; Jacobson, S.C. Ion transport in nanofluidic funnels. ACS Nano 2010, 4, 3897-3902. [CrossRef] [PubMed] 
136. Kim, S.H.; Cui, Y.; Lee, M.J.; Nam, S.W.; Oh, D.; Kang, S.H.; Park, S. Simple fabrication of hydrophilic nanochannels using the chemical bonding between activated ultrathin PDMS layer and cover glass by oxygen plasma. Lab Chip 2011, 11, 348-353. [CrossRef] [PubMed]

137. Harms, Z.D.; Mogensen, K.B.; Nunes, P.S.; Zhou, K.; Hildenbrand, B.W.; Mitra, I.; Jacobson, S.C. Nanofluidic devices with two pores in series for resistive-pulse sensing of single virus capsids. Anal. Chem. 2011, 83, 9573-9578. [CrossRef] [PubMed]

138. Nam, S.W.; Lee, M.H.; Lee, S.H.; Lee, D.J.; Rossnagel, S.M.; Kim, K.B. Sub-10-nm nanochannels by self-sealing and self-limiting atomic layer deposition. Nano Lett. 2010, 10, 3324-3329. [CrossRef] [PubMed]

139. Fouad, M.; Yavuz, M.; Cui, B. Nanofluidic channels fabricated by e-beam lithography and polymer reflow sealing. J. Vac. Sci. Technol. B 2010, 28, C6I11-C6I13. [CrossRef]

140. Chen, Y. Nanofabrication by electron beam lithography and its applications: A review. Microelectron. Eng. 2015, 135, 57-72. [CrossRef]

141. Williams, C.; Bartholomew, R.; Rughoobur, G.; Gordon, G.S.; Flewitt, A.J.; Wilkinson, T.D. Fabrication of nanostructured transmissive optical devices on ITO-glass with UV1116 photoresist using high-energy electron beam lithography. Nanotechnology 2016, 27, 485301. [CrossRef] [PubMed]

142. Mussi, V.; Fanzio, P.; Repetto, L.; Firpo, G.; Scaruffi, P.; Stigliani, S.; Valbusa, U. DNA-functionalized solid state nanopore for biosensing. Nanotechnology 2010, 21, 145102. [CrossRef] [PubMed]

143. Tian, Z.P.; Lu, K.; Chen, B. Unique nanopore pattern formation by focused ion beam guided anodization. Nanotechnology 2010, 21, 405301. [CrossRef] [PubMed]

144. Yamamoto, T.; Fujii, T. Nanofluidic single-molecule sorting of DNA: A new concept in separation and analysis of biomolecules towards ultimate level performance. Nanotechnology 2010, 21, 395502. [CrossRef] [PubMed]

145. Menard, L.D.; Ramsey, J.M. The fabrication of sub-5-nm nanochannels in insulating substrates using focused ion beam milling. Nano Lett. 2011, 11, 512-517. [CrossRef] [PubMed]

146. Angeli, E.; Manneschi, C.; Repetto, L.; Firpo, G.; Valbusa, U. DNA manipulation with elastomeric nanostructures fabricated by soft-moulding of a FIB-patterned stamp. Lab Chip 2011, 11, 2625-2629. [CrossRef] [PubMed]

147. Fanzio, P.; Mussi, V.; Manneschi, C.; Angeli, E.; Firpo, G.; Repetto, L.; Valbusa, U. DNA detection with a polymeric nanochannel device. Lab Chip 2011, 11, 2961-2966. [CrossRef] [PubMed]

148. Wu, J.; Chantiwas, R.; Amirsadeghi, A.; Soper, S.A.; Park, S. Complete plastic nanofluidic devices for DNA analysis via direct imprinting with polymer stamps. Lab Chip 2011, 11, 2984-2989. [CrossRef] [PubMed]

149. La Ferrara, V.; Aneesh, P.M.; Veneri, P.D.; Mercaldo, L.V.; Usatii, I.; Polichetti, T.; Cusano, A. Focused ion beam strategy for nanostructure milling in doped silicon oxide layer for light trapping applications. Vacuum 2014, 99, 135-142. [CrossRef]

150. Duan, C.; Wang, W.; Xie, Q. Review article: Fabrication of nanofluidic devices. Biomicrofluidics 2013, 7, 026501. [CrossRef] [PubMed]

151. Peng, R.; Li, D. Fabrication of nanochannels on polystyrene surface. Biomicrofluidics 2015, 9, 024117. [CrossRef] [PubMed]

152. Peng, R.; Li, D. Fabrication of polydimethylsiloxane (PDMS) nanofluidic chips with controllable channel size and spacing. Lab Chip 2016, 16, 3767-3776. [CrossRef] [PubMed]

(C) 2017 by the authors. Licensee MDPI, Basel, Switzerland. This article is an open access article distributed under the terms and conditions of the Creative Commons Attribution (CC BY) license (http://creativecommons.org/licenses/by/4.0/). 